Table.

\begin{tabular}{|c|c|c|c|c|c|}
\hline & & Robust & Pre-frail & Frail & p \\
\hline \multirow[t]{2}{*}{$\begin{array}{l}\text { Body mass } \\
\text { index }\left(\mathrm{kg} / \mathrm{m}^{2}\right)\end{array}$} & Knee OA & $\begin{array}{c}24.13 \\
{[23.74-24.53]}\end{array}$ & $\begin{array}{c}25.07 \\
{[24.83-25.32]}\end{array}$ & $\begin{array}{c}25.46 \\
{[25.14-25.78]}\end{array}$ & $<0.0001$ \\
\hline & RA & $23.73[23.04-24.42]$ & $\begin{array}{c}23.58 \\
{[23.20-23.97]}\end{array}$ & $\begin{array}{c}24.97 \\
{[24.28-25.66]}\end{array}$ & 0.001 \\
\hline \multirow[t]{2}{*}{$\begin{array}{l}\text { Hemoglobin, } \\
\text { g/dL }\end{array}$} & Knee OA & $\begin{array}{c}13.53 \\
{[13.36-13.70]}\end{array}$ & $\begin{array}{c}13.51 \\
{[13.42-13.61]}\end{array}$ & $\begin{array}{c}13.27 \\
{[13.14-13.40]}\end{array}$ & 0.004 \\
\hline & RA & $13.63[13.34-13.92$ & $\begin{array}{c}13.30 \\
{[13.14-13.46]}\end{array}$ & $\begin{array}{c}13.15 \\
{[12.85-13.45]}\end{array}$ & 0.060 \\
\hline \multirow[t]{2}{*}{$\begin{array}{l}\text { White blood cell, } \\
10^{3} / \mu \mathrm{L}\end{array}$} & Knee OA & $5.50[5.29-5.71]$ & $5.94[5.81-6.07]$ & 6.41 [6.24-6.58] & ]$<0.0001$ \\
\hline & RA & 5.47 [5.13-5.82] & $5.85[5.64-6.06]$ & 6.68 [6.32-7.03] & $<0.0001$ \\
\hline \multirow[t]{2}{*}{ Platelet, $10^{3} / \mu \mathrm{L}$} & Knee OA & $\begin{array}{c}246.03 \\
{[238.52-253.53]}\end{array}$ & $\begin{array}{c}258.13 \\
{[253.44-262.82]}\end{array}$ & $\begin{array}{c}259.96 \\
{[253.40-266.53]}\end{array}$ & 0.045 \\
\hline & RA & $\begin{array}{c}237.49 \\
{[222.91-252.06]}\end{array}$ & $\begin{array}{c}255.30 \\
{[247.50-263.10]}\end{array}$ & $\begin{array}{c}262.04 \\
{[248.32-275.77]}\end{array}$ & 0.038 \\
\hline \multirow[t]{2}{*}{$\begin{array}{l}\text { Serum creati- } \\
\text { nine, } \mathrm{mg} / \mathrm{dL}\end{array}$} & Knee OA & $\begin{array}{c}0.734 \\
{[0.712-0.756]}\end{array}$ & $\begin{array}{c}0.764 \\
{[0.751-0.777]}\end{array}$ & $\begin{array}{c}0.861 \\
{[0.826-0.895]}\end{array}$ & $<0.0001$ \\
\hline & RA & $\begin{array}{c}0.732 \\
{[0.686-0.779]}\end{array}$ & $\begin{array}{c}0.783 \\
{[0.762-0.805]}\end{array}$ & $\begin{array}{c}0.917 \\
{[0.840-0.994]}\end{array}$ & $<0.0001$ \\
\hline \multirow[t]{2}{*}{$\begin{array}{l}\text { CKD-EPI eGFR, } \\
\mathrm{ml} / \mathrm{min}\end{array}$} & Knee OA & $\begin{array}{c}88.54 \\
{[86.77-90.31]}\end{array}$ & $\begin{array}{c}83.89 \\
{[82.89-84.88]}\end{array}$ & $\begin{array}{c}76.22 \\
{[74.80-77.63]}\end{array}$ & $<0.0001$ \\
\hline & RA & 94.30 [90.77-97.82] & $\begin{array}{c}85.86 \\
{[84.00-87.73]}\end{array}$ & $\begin{array}{c}74.76 \\
{[70.91-78.61]}\end{array}$ & $<0.0001$ \\
\hline \multirow[t]{2}{*}{ EQ-5D } & Knee OA & $\begin{array}{c}0.933 \\
{[0.921-0.944]}\end{array}$ & $\begin{array}{c}0.804 \\
{[0.793-0.815]}\end{array}$ & $\begin{array}{c}0.635 \\
{[0.616-0.653]}\end{array}$ & $<0.0001$ \\
\hline & RA & $\begin{array}{c}0.966 \\
{[0.953-0.979]}\end{array}$ & $\begin{array}{c}0.857 \\
{[0.839-0.874]}\end{array}$ & $\begin{array}{c}0.666[0.619 \\
-0.713]\end{array}$ & $<0.0001$ \\
\hline
\end{tabular}

Acknowledgments: None

Disclosure of Interests: None declared

DOI: 10.1136/annrheumdis-2020-eular.5182

\section{AB0867 INCREASED ADIPONECTIN LEVELS ARE ASSOCIATED WITH HIGHER RADIOGRAPHIC SCORES IN THE KNEE JOINT, BUT NOT IN THE HAND JOINT: THE DONG-GU STUDY}

J. H. Kang ${ }^{1}$, S. E. Choi ${ }^{1}$, H. Xu ${ }^{1}$, D. J. Park', S. S. Lee ${ }^{1}{ }^{1}$ Chonnam National University Medical School \& Hospital, Gwangju, Korea, Rep. of (South Korea)

Background: Several studies have evaluated the association between serum adiponectin levels and knee and hand osteoarthritis (OA), with mixed results.

Objectives: The aim of this study was to investigate the relationship between $\mathrm{OA}$ and serum adiponectin levels according to the radiographic features of knee and hand $\mathrm{OA}$.

Methods: A total of 2,402 subjects were recruited from the Dong-gu Study. Baseline characteristics were collected via a questionnaire, and X-rays of knee and hand joints were scored by a semi-quantitative grading system. The relationship between serum adiponectin levels and radiographic severity was evaluated by linear regression analysis.

Results: Subjects with higher tertiles of serum adiponectin were older and had a lower body mass index than those with lower tertiles. In the knee joint scores, serum adiponectin levels were positively associated with the total score $(P<0.001)$, osteophyte score $(P=0.003)$, and joint space narrowing (JSN) score $(P<0.001)$ among the three tertiles after adjustment for age, sex, body mass index, smoking, alcohol consumption, education, and physical activity. In the hand joint scores, no association was found between serum adiponectin levels and the total score, osteophyte score, JSN score, subchondral cyst score, sclerosis score, erosion score, and malalignment score among the three tertiles after adjustment.

Conclusion: In this study, we found that increased adiponectin levels were associated with higher radiographic scores in the knee joint, but not in the hand joint, suggesting different pathophysiologic mechanisms in the development of OA.

Disclosure of Interests: None declared

DOI: 10.1136/annrheumdis-2020-eular.1677

\section{AB0868 \\ EFFICACY AND SAFETY OF PULSED ELECTROMAGNETIC FIELDS IN THE TREATMENT OF OSTEOARTHRITIS: RESULTS OF A MULTICENTER BLIND PLACEBO-CONTROLLED STUDY.}

A. Karateev ${ }^{1}$, E. Pogozheva ${ }^{1}$, M. Sukhareva ${ }^{2}$, A. Lila ${ }^{2} .{ }^{1}$ Nasonova Research Institute of Rheumatology, Moscow, Russian Federation; ${ }^{2}$ Nasonova Research Institute of Rheumatology, Moscow, Russian Federation

Background: Pulsed electromagnetic fields (PEMF) is a well - known method of non-pharmacological treatment that is widely used in knee osteoarthritis (KOA). Objectives: To evaluate the effectiveness and safety of PEMF in KOA.

Methods: The study group consisted of $231 \mathrm{KOA}$ patients, $77.9 \%$ of women, age $61.9 \pm 12.2$ years, BMI $30.6 \pm 5.8 \mathrm{~kg} / \mathrm{m} 2$, average disease duration 5.0 [2.0;10.0] years. Patients were randomly assigned to two groups. Group 1 patients received PEMF for 14 days using a device that creates a low-frequency pulsed magnetic field, group 2-a false PEMF (a device that completely simulates a working device, but does not create a magnetic field). We evaluated the dynamics of the WOMAC index, the severity of pain at rest and when moving on a $100-\mathrm{mm}$ visual analog scale (VAS), the need for non-steroidal anti-inflammatory drugs (NSAIDs), and the evaluation of the patient's treatment result (on a 5-point scale).

Results: Statistically significant reduction in pain, stiffness, and improved function was observed in both true PEMF and false PEMF. Thus, the WOMAC pain in Group 1 decreased from 231 [180; 290] to 110 [60; 166.3], p<0.001; in Group 2 from 212.4 $[145 ; 260]$ to $143[76.5 ; 200], p<0.001$, the severity of pain in rest (VAS) decreased in Group 1 from 47 [27.8; 60] to $20[10 ; 30], p<0.001$; in Group 2 from 40 [20; 57.5] to 20 [7.5; 40], p<0.001. After therapy, the need for NSAIDs also decreased: in Group 1 NSAIDs were canceled or reduced in $33.1 \%$ of patients, in Group 2 - in $16.8 \%$ $(p=0.006)$. For all indicators, the dynamics were statistically more significant in Group 1 than in Group 2. The result of treatment as "good" and "excellent" was evaluated by $58.5 \%$ of patients in Group 1 and $39.8 \%$ of patients in Group 2, $p<0.001$. No serious adverse reactions were observed when using true and false PEMF. Two patients who received false PEMF therapy was interrupted due to increased joint pain.

Conclusion: PEMF with short-term use provides a significant improvement in the condition of KOA patients. PEMF is well tolerated and does not cause serious complications.

Disclosure of Interests: None declared

DOI: 10.1136/annrheumdis-2020-eular.3973

\section{AB0869 CLINICAL FEATURES OF WOMEN WITH KNEE OSTEOARTHRITIS AT DIAGNOSIS IN CAMEROON, SUB-SAHARAN AFRICA}

F. Kemta Lekpa ${ }^{1,2}$, A. Tidjong Kamkui ${ }^{3}$, H. Namme Luma ${ }^{3}$, S. P. Choukem ${ }^{1,2}$ ${ }^{1}$ Douala General Hospital, Internal Medicine, Douala, Cameroon; ${ }^{2}$ University of Dschang, Faculty of Medicine, Dschang, Cameroon; ${ }^{3}$ Douala General Hospital, Douala, Cameroon

Background: To the best of our knowledge, no study has been done in sub-Saharan Africa among those who suggest that knee osteoarthritis is more severe in women.

Objectives: To assess differences in features of knee osteoarthritis between female and male patients in a sub-Saharan Cameroonian population.

Methods: A cross-sectional study from December 2018 to April 2019 conducted in the Rheumatology Unit of the General Hospital, Douala, Cameroon. We included patients with a recent diagnosis of knee osteoarthritis according to 1986 ACR criteria and Kellgren-Lawrence radiographic grading $\geq 2$. Sociodemographic, clinical, radiographic and therapeutic data at diagnosis were collected. Assessment of the functional disability was done using the Lequesne algofunctional index more adapted to Africans than WOMAC index. We compared these data between women and men. A $p<0.05$ was considered to be statistically significant.

Results: We screened 168 patients with the diagnosis of knee osteoarthritis. Seventeen patients with Kellgren-Lawrence radiographic grading at 1 were excluded. Then, we included 151 patients (120 women and $31 \mathrm{men}$ ) in the final analysis. The main characteristics of patients at diagnosis are summarized in Table 1. Knee osteoarthritis in women was characterized by a low level of education, a low financial income, and a high frequency of obesity. There was no difference between women and men for age at diagnosis, place of residence, intensity of pain, functional disability, number of compartments of the affected knee, Kellgren-Lawrence radiographic grading, and treatment previously received. 
Table 1. Main characteristics of patients with knee osteoarthritis at diagnosis

\begin{tabular}{|c|c|c|c|c|}
\hline Parameters & $\begin{array}{l}\text { Total population } \\
\text { Mean (SD) }\end{array}$ & $\begin{array}{c}\text { Male } \\
\text { Mean (SD) }\end{array}$ & $\begin{array}{c}\text { Female } \\
\text { Mean (SD) }\end{array}$ & $p$ \\
\hline \multicolumn{5}{|l|}{ Age (years) } \\
\hline Mean age & $59.88(12.8)$ & $61.48(14.38)$ & $59.46(12.41)$ & 0.43 \\
\hline$<40$ & $10(6.6)$ & $4(12.9)$ & $6(5)$ & 0.24 \\
\hline $40-65$ & $87(57.6)$ & $14(45.16)$ & $73(60.83)$ & 0.17 \\
\hline$>65$ & $54(35.8)$ & $13(41.94)$ & $41(34.17)$ & 0.55 \\
\hline \multicolumn{5}{|l|}{ Residence } \\
\hline Rural & $37(24.5)$ & $10(32.26)$ & $27(22.5)$ & 0.37 \\
\hline Urban & $114(75.5)$ & $21(67.74)$ & $93(77.5)$ & 0.37 \\
\hline \multicolumn{5}{|l|}{ Level of education } \\
\hline Primary & $40(26.5)$ & $3(9.68)$ & $37(30.83)$ & 0.03 \\
\hline Secondary & $66(43.7)$ & $9(29.03)$ & $57(47.5)$ & 0.09 \\
\hline University & $35(23.2)$ & 19(61.29) & $16(13.33)$ & 0.0000 \\
\hline Illiterate & $10(6.6)$ & 0 & $10(8.33)$ & 0.20 \\
\hline Duration of $\mathrm{OA}$ (months) & $38(44.9)$ & $39.7(58.92)$ & $37.59(40.92)$ & 0.81 \\
\hline \multicolumn{5}{|l|}{ Pain } \\
\hline VAS pain (mean) & $5.2(1.6)$ & $5(1.34)$ & $5.34(1.68)$ & 0.29 \\
\hline Mild pain & $25(16.56)$ & $4(12.9)$ & $21(17.5)$ & 0.73 \\
\hline Moderate pain & $94(62.25)$ & $24(77.42)$ & $70(58.33)$ & 0.08 \\
\hline Severe pain & $32(21.19)$ & $3(9.68)$ & $29(24.17)$ & 0.13 \\
\hline Joint effusion & $28(18.5)$ & $4(12.90)$ & $24(20)$ & 0.51 \\
\hline \multicolumn{5}{|l|}{ BMI } \\
\hline Mean BMI & $32.42(6.25)$ & $26.89(4.05)$ & $31.33(6.41)$ & 0.0003 \\
\hline Normal & $30(19.87)$ & $11(35.48)$ & $19(15.83)$ & 0.02 \\
\hline Overweight & $46(30.46)$ & $14(45.16)$ & $32(26.07)$ & 0.07 \\
\hline Obesity & $65(49.67)$ & $6(19.35)$ & $69(57.5)$ & 0.003 \\
\hline \multicolumn{5}{|l|}{ Lequesne index } \\
\hline Mean Lequesne index & $8.6(2.4)$ & $8.32(2.53)$ & $8.77(2.4)$ & 0.35 \\
\hline Moderate handicap & $40(26.49)$ & $9(29.03)$ & $31(25.83)$ & 0.89 \\
\hline Severe handicap & $64(42.38)$ & $12(32.71)$ & $52(43.33)$ & 0.79 \\
\hline Very severe handicap & $37(24.5)$ & $8(25.81)$ & $29(24.17)$ & 1 \\
\hline \multicolumn{5}{|l|}{ Kellgren-Lawrence grading } \\
\hline Grade 2 & $81(53.6)$ & 19(61.29) & $62(51.67)$ & 0.44 \\
\hline Grade 3 & $55(36.4)$ & $9(29.03)$ & $46(38.33)$ & 0.45 \\
\hline Grade 4 & $15(10)$ & $3(9.68)$ & $12(10)$ & 1 \\
\hline \multicolumn{5}{|l|}{ Compartment involved } \\
\hline 1 & 18(11.92) & $6(19.35)$ & $12(10)$ & 0.26 \\
\hline 2 & $28(18.54)$ & $4(12.9)$ & $24(20)$ & 0.51 \\
\hline 3 & $105(69.6)$ & $21(67.74)$ & $84(70)$ & 0.98 \\
\hline Medial femoro-tibial & $128(84.77)$ & $25(80.65)$ & $103(85.83)$ & 0.66 \\
\hline Lateral femoro-tibial & $117(77.48)$ & $23(74.19)$ & $94(78.33)$ & 0.80 \\
\hline Femoro-patellar & $144(95.36)$ & $29(93.55)$ & $115(95.83)$ & 0.95 \\
\hline
\end{tabular}

Conclusion: Apart from obesity, characteristics of knee osteoarthritis seems to be similar in women and men at diagnosis in Cameroon.

Disclosure of Interests: None declared

DOI: 10.1136/annrheumdis-2020-eular.5187

\section{\begin{tabular}{|l|l} 
AB0870 & PAIN AND FUNCTIONAL OUTCOME OF PERIPHERAL
\end{tabular} BLOOD DERIVED STEM CELLS IN PRIMARY OSTEOARTHRITIS OF KNEE AT LOW RESOURCES SETTING: A PHASE II PILOT RCT}

M. R. Khasru ${ }^{1}{ }^{1}$ Bangabandhu Sheikh Mujib Medical University, Physical Medicine and Rehabiliation, Dhaka, Bangladesh

Background: Osteoarthritis (OA) of the knee is one of the main causes of musculoskeletal disability. Osteoarthritis is now often considered as organ failure. Because of limitations in the effectiveness of conventional management options, alternative possibilities such as cell based therapies are approaching into vogue

Objectives: To assess the effectiveness of peripheral bold derived stem cells (PBSCs) therapy for primary OA knee.

Methods: This phase-II pilot RCT was conducted after the IRB ethical clearance. Patients attending PM\&R department of BSMMU having $\mathrm{KL}$ grade III osteoarthritis knee those fulfilled the selection criteria were considered as the sample. All respondents were divided to into two groups by using randomization technique. In control group, 15 respondents received standard care for Knee Osteoarthritis. In PBSCs group, 15 cases received with single dose autologous peripheral blood derived stem cells (PBSCs). Stem cells were harvested using G-CSF 30MU and CD34 stem cells were collected through apheresis. Quality was ensured measuring cell viability and surface antigen. All respondents were assessed before treatment and at week 4, week 12 and week 24 for pain reduction and for functional improvement using Visual Analogue Scale (VAS 0-10 cm) and validated Bengali WOMAC questionnaire. Joint sonography was done before treatment, at 12 week and 24 week after treatment commencement.
Results: Female were $60 \%$ and $67 \%$ in control and PBSCs group respectively. The mean age was $56.3 \pm 6.7$ and $55.8 \pm 7.3$ year in control and PBSCs. After 12 weeks of stem cell therapy, pain reduction and functional significant improvement was observed in both groups. However, after 24 weeks further significant pain reduction, functional improvement was observed in PBSCs group. More over, the cartilage thickness measured by high frequency ultrasound and the mean cartilage thickness was increased by $0.14 \mathrm{~mm}$ from the baseline among PBSCs group.

Conclusion: PBSCs is promising in patients with primary OA knee. Further large scale research is solicited.

References:

[1] Dubey, N., Mishra, V., Dubey, R., Syed-Abdul, S., Wang, J., Wang, P. and Deng, W. (2018). Combating Osteoarthritis through Stem Cell Therapies by Rejuvenating Cartilage: A Review. Stem Cells International, 2018 pp.1-13.

[2] Jevotovsky, D., Alfonso, A., Einhorn, T. and Chiu, E. (2018). Osteoarthritis and stem cell therapy in humans: a systematic review. Osteoarthritis and Cartilage, 26(6), pp.711-729.

[3] Wang, A., Feng, Y., Jia, H., Zhao, M. and Yu, H. (2019). Application of mesenchymal stem cell therapy for the treatment of osteoarthritis of the knee: $A$ concise review. World Journal of Stem Cells, 11(4), pp.222-235.

Acknowledgments: Department of Transfusion Medicine, BSMMU

Disclosure of Interests: None declared

DOI: 10.1136/annrheumdis-2020-eular.4740

\section{AB0871 OSTEOARTHRITIS IN OBESE PATIENTS}

S. Lapshina ${ }^{1}$, L. Feiskhanova ${ }^{1}$, A. Nurmieva ${ }^{2}$, K. Sadriev ${ }^{2}{ }^{1}$ Kazan State Medical University, Hospital Therapy, Kazan, Russian Federation; ${ }^{2}$ Kazan State Medical University, Kazan, Russian Federation

Background: Obesity is a recognized risk factor for osteoarthritis (OA) of the knee joints, which is associated with increased biomechanical stress. However the association of OA with metabolic syndrome is more multifaceted, since overweight and obese people have a similar increased risk of OA of the hand joints that do not carry weight, due to systemic factors.

Objectives: To identify the features of the course of $O A$ in overweight patients. Methods: 52 patients with an established diagnosis of osteoarthritis were examined: women $-84.6 \%$, men $-15.4 \%$, average age $-60.9 \pm 8.9$ years (32 to 78 years). Clinical examination, calculation of body mass index (BMI), determination of the X-ray stage of OA according to the Kellgren and Lawrence system; ultrasound examination of the knee joints; assessment of the severity of pain according to visual analog scale (VAS); the index WOMAC was used to evaluate pain, stiffness and physical function. We evaluated the quality of life by EQ-5D.

Results: The duration of OA was 8.75 [2.58; 26] years. The distribution of patients according to the X-ray stage of OA: I $-9.6 \%$, II $-57.6 \%$, III $-26.9 \%$, IV - $5.9 \%$ of patients. The BMI range was from 21 to $43 \mathrm{~kg} /$. A BMI up to $30 \mathrm{~kg} / \mathrm{was}$ found in 22 patients: $17.3 \%$ - normal weight, $25 \%$ - excess body weight. Thirty patients has BMI more than $30 \mathrm{~kg} /$ : I degree $-38.4 \%$, II degree $-15.3 \%$, III degree - $4 \%$. Obese patients rated pain according to the VAS scale of 1.3 the score is more intensively than patients with a $B M I<30 \mathrm{~kg} / \mathrm{m}^{2}(\mathrm{p}<0.001)$. A detailed examination of each subsequent degree of obesity revealed a tendency to reduce the pain syndrome from 7.52 points at 1 degree of obesity to 5 points at 3 degrees of obesity $(p<0.001)$. With increasing body weight, there was an increase in difficulties in daily activities according to the WOMAC $(p<0.05)$. Reactive knee synovitis was detected in $25(48 \%)$ patients. The incidence of synovitis in patients with a $\mathrm{BMI}<30 \mathrm{~kg} / \mathrm{m}^{2}$ is $27 \%$, with a BMl $>30 \mathrm{~kg} / \mathrm{m}^{2}$ is $68 \%$. Patients with obesity of $1^{\text {st }}$ degree had synovitis in $65 \%, 2^{\text {nd }}$ degree $-75 \%, 3^{\text {rd }}$ degree $-84 \%$ of cases $(p<0.05)$. A high correlation between the $x$-ray stage of OA and BMI $(r=0.74$ $p<0.001$ ) was revealed. According to the EQ-5D questionnaire, patients with the $1^{\text {st }}$ degree of obesity $(2.31 \pm 1.3)$ were very anxious, but the level of anxiety decreases in patients with $3^{\text {rd }}$ degree of obesity $(1.44 \pm 0.9)$ and it's equal to that in individuals with normal body weight $(1.33 \pm 0.8)$.

Conclusion: The existence of obesity in patients with $\mathrm{OA}$ is associated with an increase in pain, a significant decrease in functional ability, a presence of reactive synovitis of the knee joints, aggravation of the X-ray stage of $\mathrm{OA}$, and the appearance of anxiety and depression. However, with the further progression of obesity, the levels of anxiety for one's condition decrease.

References:

[1] Felson DT, Zhang Y, Hannan MT et al. Risk factors for incident radiographic knee osteoarthritis in the elderly: the Framingham study. Arthritis Rheum. 1997; 40: 728-733.

[2] Huffman KM. Osteoarthritis and the metabolic syndrome: more evidence that the etiology of OA is different in men and women. 2012; 20 (7): 603-604 